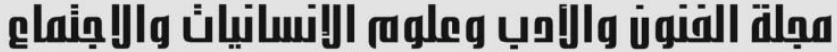 \\ Journal of Arts, Literature, Humanities and Social Sciences www.jalhss.com

\section{Family Business Conflict Management}

\author{
Narmen Wali Ali \\ Department of Finance and Banking - Salahaddin University - Erbil \\ Ministry of Higher Education and Scientific Research -Iraq \\ Email: kawa.kamal455@gmail.com
}

\begin{abstract}
Family-owned businesses mature and grow in terms of age, family owners and employees, and the value of wealth generated since its inception. Consequent to such growth is the possibility of occurrence and increment of conflict owing to strategic and objective business goal differences. Often, rivalry among the members of the family owning the business is bound to result in interpersonal conflict. This paper thus seeks to research the most common causes of conflict in the context of family-owned or controlled enterprises and reviews past studies to present its methodology for possible recommended approaches to resolution of such conflict for business continuity.
\end{abstract}

Keywords: Family Business, Conflict Management. 


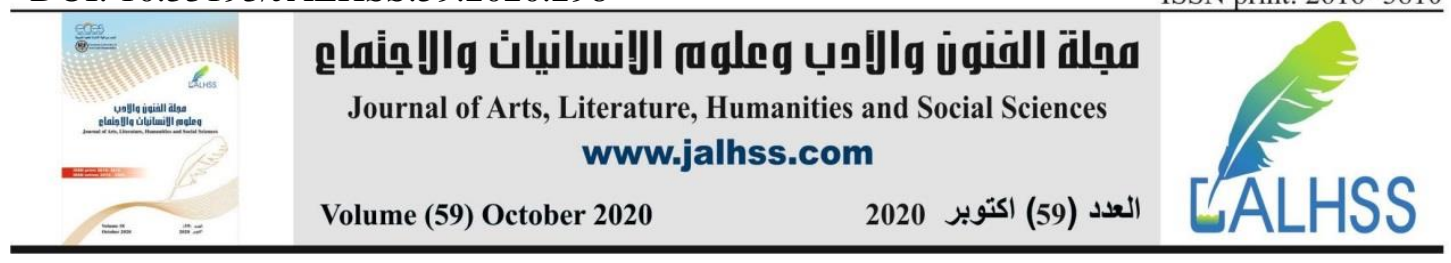

\section{Introduction}

Notably, there is a vast number of businesses that are family entities across the world. In the US alone, an estimated percentage of between 80 and 95 of all business enterprises are controlled or owned by families (Alderson, 2015). An overwhelming third of the poor and standard 500 indices listed companies and close to $36 \%$ of the Fortune 500 companies are family controlled or owned. Indeed, in the South American, Latin, Asian and European contexts, the economies are well dominated by family-owned enterprises. This is inclusive of large-scale ventures including Wal-Mart, Ikea, Cargill, Tyson Foods, AstraZeneca, Michelin, Volkswagen, Samsung, Novartis and Ford (Alderson, 2015). Even so, a vast tally of the businesses making up these economies are listed as small or medium enterprises which, in most cases, are privately controlled and do not have stockholders from outside the family. Family-owned business enterprises fill a significant gap in the business ownership framework. With little regard for the business size and structure, family-owned and controlled enterprises exhibit unique problems, issues, and complexities which are alien to and never experienced by non-family-owned enterprises (Alderson, 2015). Such challenges are related to multi-generational succession problems, incompetent family workforce, interpersonal conflicts, substance and drug abuse issues, divorce and separation, non-working family members, and sibling rivalry. These challenges worsen as the family member trees and generations grow over time. An increase in the number of family members affiliated to a business implies a correlating increase in dysfunctional interpersonal conflict volume.

\section{Literature Review}

Families are characterized by sibling rivalry which makes family undertakings dysfunctional. Families with businesses often interact on a daily basis as opposed to popular thought that such families may interact on special occasions and holidays. The introduction of the family unit to the business has both beneficial and deleterious effect on the business (Alderson, 2015). Healthy family relations result in business competitive advantage. In addition, the business is also able to make decisions more quickly which has the impact of presenting the business with opportunities which may not be available for other businesses. Businesses owned or controlled by tight-knit families tend to make decisions fast which is critical for business growth.

A major issue that family-owned businesses encounter is generational conflict. Families are keen to observer the spirit of togetherness and harmony to an extent that they would eliminate any opinion differences thereby stifling and preventing the possibility of healthy and constructive debate (Sherpherd \& Haynie, 2010). There is difficulty for children to disagree with parents on the basis of such disagreement being termed as disruptive and disloyal. The absence of open communication minimizes the possibility of healthy discussion, forgoing the whole strategic planning process, and missing out on potential business opportunities (Sherpherd \& Haynie, 2010). The outcomes entail forceful status quo dependence which, in turn, triggers reduced market share, inhibits investment in emergent and new business areas, inability to decipher competitive threats, as well as the stagnation of production. 


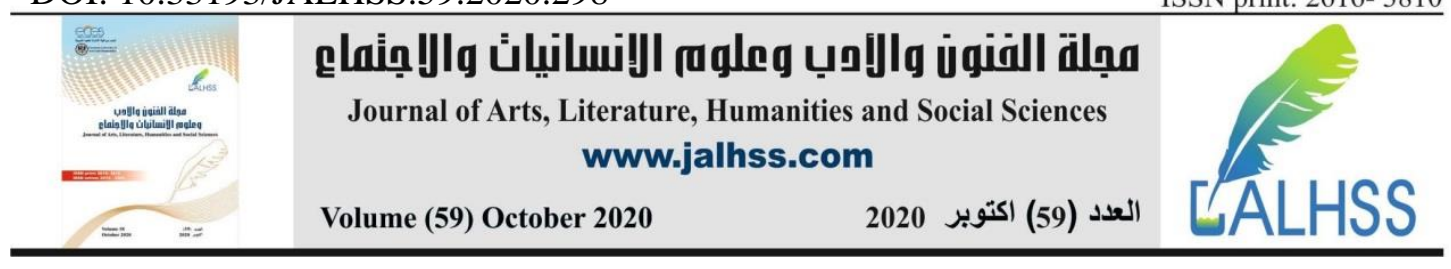

Family business conflict often stems from siblings. While there is little evidence for rivalry and conflict among second-generation family members and subsequent deleterious impact on family-owned business, research indicates that sibling conflict plays a critical role in affecting business owned by families (Wally \& Baum, 2003). Arguably, the moment family members are in conflict, they tend to self-isolate from family business. In the end, it is expected such self-isolating partners are recalled back to the business for private reasons. Overdependence on a single entrepreneurial founder emphasizes on centralized process of decision making as commonly seen in first-generation family enterprises (Wally \& Baum, 2003). This means that the founder is likely to make decisions in most cases, while a few other founders may advance at the voting or seeking consensus with other family members. While the influence of the founder may help the future generations to stay focused on the vision and mission of the business, as well as the observation of such values as meeting the interests and needs of customers, the community, and long-term employees. However, it is associated with the negative influence of limiting the ability of successive generations in making independent decisions which triggers exit of generational members from the business (Wally \& Baum, 2003).

Succession forms another serious problem faced by family-owned business practitioners, especially in handing over the business ownership from one generation to another. Researchers are in consensus that of all family-controlled business, only $30 \%$ and between $10 \%$ and $15 \%$ of these businesses survive successful transfer to the second and third generations respectively, while a meagre $4 \%$ of such businesses survive into the fourth generation ownership transfer (Schneewind \& von Schlippe, 2015). Arguably, with little wealth diversification, succession is a major deleterious aspect for families since a significant share of the business wealth is often controlled by the business family. Thus, succession implies loss of wealth and social status of the business family. Perhaps, this explains the high rates of bankruptcy of family businesses upon the death of their founders. Small scale family businesses are more susceptible to business failure owing to the absence of a viable succession plan as opposed to the effects of competitive or financial market forces (Schneewind \& von Schlippe, 2015). A majority of research studies conducted on family businesses reveal that a major cause for failure of succession entails an outward lack of viable decision making. Slow decision making in turn negatively affects the performance of businesses. Research indicates that slow decision making results from interpersonal family conflict, poor decision making, poor planning, and poor communication. Indeed, it is not surprising that some family-owned businesses lack a clear and defined plan and procedure for the eventual continuation of the business, as well as lack of other critical roles and procedures including CEO replacement and the due process of successor selection and training (Schneewind \& von Schlippe, 2015).

This type of business further faces the challenges associated with owner benefits and compensation. The variant roles prescribed to different family members in relation to the operation of the business. With such roles, it follows that family members duly qualify for the two primary modes of reward and remuneration of family employees which include dividends and payroll (Salvato \& Sharma, 2014). It is noteworthy that 


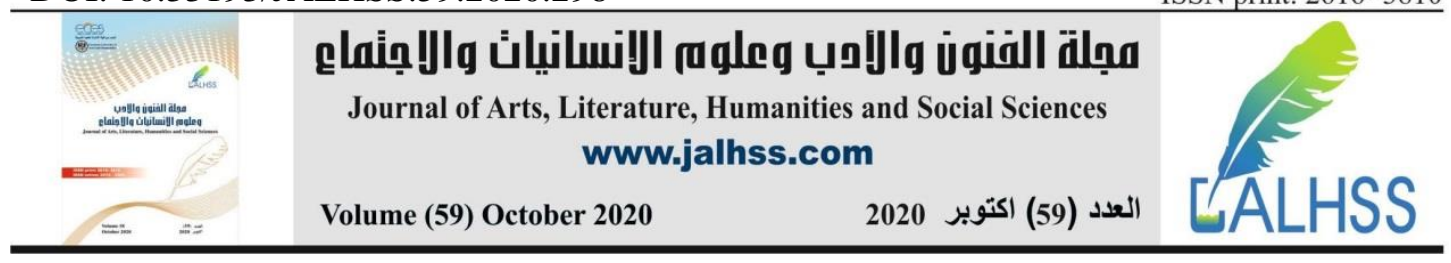

these modes must be separated. As stakeholders in the business, family members can take variant positions as the owners and controllers, the management, or employees. These members may have all the three roles while others can only play single role (Salvato \& Sharma, 2014). Take the instance of a company which strategically must heavily invest in technology if it is to gay a competitive edge and remain relevant in the market into the future, it demands that the managers and employees are compelled to logically comprehend the demand for the necessary expenditure and perceive the positive aspect in it (Alderson, 2015). Even so, it is possible that a member who has not worked in the family business and is only subject to reception of dividends might not understand the need and significance of such investment. Such a member is likely to against the need for such investment as it is bound to reduce their ownership income. However, since the non-employed member duly enjoys partial company ownership, they legally qualify to make such crucial vote (Alderson, 2015). A shareholder becomes problematic in an organization especially when such a firm is managed by the owner since each of these two parties are inclined to the achievement of different objectives. Thus, it is important for stakeholders of a family-owned firm to adopt effective communication (Salvato \& Sharma, 2014). Compensation conflicts can be avoided through clear communication of the pat ranges for different stakeholder roles and positions as aided by benchmarking of current payment rates in the firm's marketplace. Subsequently, each employee regards compensation as a fair exercise.

Estate planning is another source of problems and conflict in family-owned businesses. The owner of a family business may have a good intention of equally splitting the family firm among all children, but such intention may be disastrously affected by the second or third generations (Yanes, 2015). This can be illustrated by a family business owner with two children who might be inclined to split the firm to the children, with each sibling receiving $50 \%$ of the inheritance. Into the future, one of the siblings could have one child while the other has four. This implies that upon successful inheritance, a single stakeholder will hold 50\% ownership and could exercise significant power on the firm while the other four stakeholders will only own $12.5 \%$ of the firm and, consequently, will wield lesser power on the organization (Alderson, 2015). For power balance, the four siblings must in all cases combine their power if they are to strike organizational power balance with the individual enjoying $50 \%$ ownership. Such estate planning system is bound to trigger serious organizational conflict since the different family branches will be entitled to greater ownership than others. Such scenario was never the conception of the founder of the family business as the founder was driven by good intentions and sought fairness from the initial estate planning and sharing (Alderson, 2015).

Family businesses face the challenge of possible destructive entitlement. Families may be involved in business together, with such association suffering the consequences of an earlier perceived injustice. The aggrieved party may seek association with another stakeholder with intent to get even and punish other stakeholders against whom they hold the grudge (Li \& Jones, 2017). This yields a situation referred to as destructive entitlement. Such scenario can persist into future 


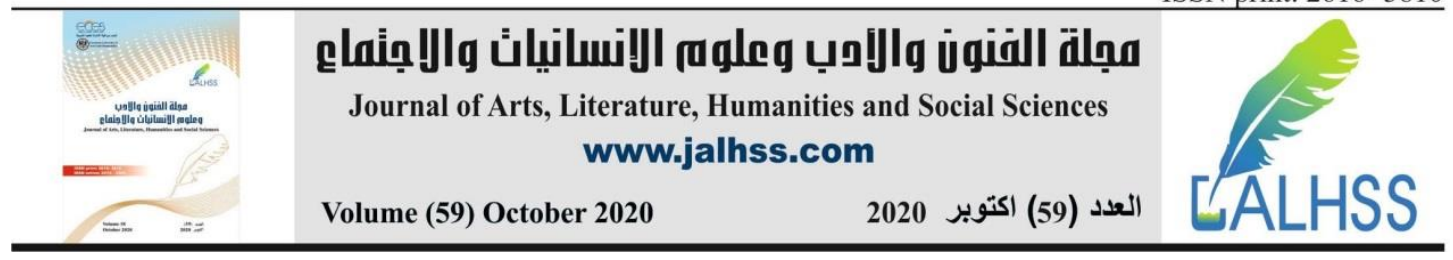

generations with a single branch of the family begrudging another thereby keeping the conflict alive. Effort made with intent to compromise or repair is received with contempt and regarded as an act of betrayal (Li \& Jones, 2017). Past unfair treatment victims feel justified to revenge either by ignoring or mistreating others. With repetitive patterns of retaliation, offense, and hurt over generations, the family business adapts to it as a normal way of life. Should such tendency be encouraged to progress, the conflicting parties may harbour bitterness which may yield in emotional cut-off. In an effort to avoid resultant pain, the parties in conflict opt not to converse (Schjoedt, Monsen, Pearson, Barnett, \& Chrisman, 2014). Such relationship is likely to be passed down to children thereby making it a generational conflict with the recommended solutions not achieving any effectiveness. Such dynamism is may cause extreme destruction and demands proactive address by professionals with the capacity to engage the members in conflict and ensure fresh start to the establishment of communication and trust. The professionals can recommend the warring parties to work toward the achievement of the objectives set forth by vision and mission of the firm as the basic past injustice reconciliation step (Schjoedt, Monsen, Pearson, Barnett, \& Chrisman, 2014).

Family businesses also face the problem of gender conflict. For many past generations, families in South America, Middle East and Europe have been observing the primogeniture law which demands that the estate is subject to inheritance by the oldest male (Alderson, 2015). This has forced many women with impeccable qualifications to exit from serving in family businesses and opted to seek career and employment elsewhere. However, there has been change in gender roles and conflict in family businesses in the past decade with more women increasingly occupying leadership positions in family businesses with the rate of women becoming family business successors increasing (Alderson, 2015). In addition, women tend to have reduced conflicts with their fathers as founders or owners of family businesses which implies reduced competition for succession and ownership. Compared to men, succession with males is more problematic with fathers as family business owners, especially when the children and father are in their twenties to thirties and forties to fifties respectively (Karam, Filho, \& Abib, 2019). As both parties get older, there is inverse reduction of competition and the working relationship between father and sons significantly improves. The family member life cycle stage awareness is a critical tool in this context, and it is advised future and potential successors should work elsewhere ahead of joining the family business stakeholder list. Upon joining the family firm, such members bring along different expertise, knowledge, and skill sets which increase the respect accorded to the younger generation while limiting conflict (Harvey \& Evans, 1994). 


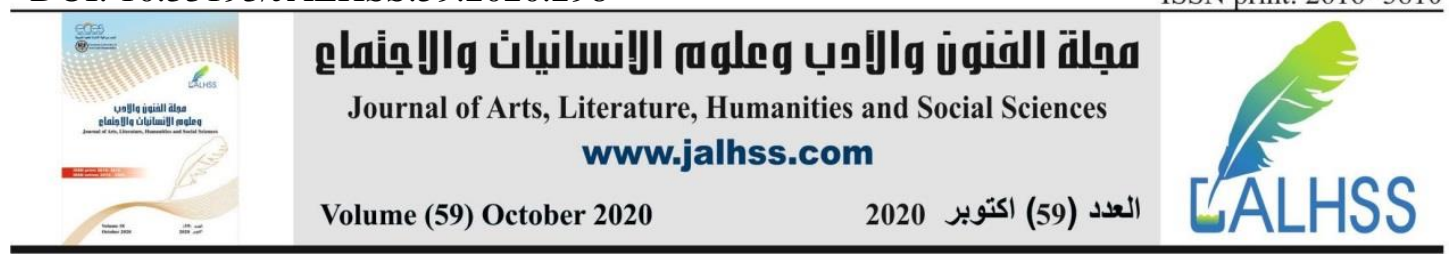

\section{Methodology}

This study undertakes desk or secondary research which entails the utilization of already existing data to derive given conclusions. The decision of undertaking secondary research was further influenced by the measures of COVID-19 containment which demand little contact between the researcher and prospective respondents. In this research methodology, the existing data is summarised and collated to enhance the general viability and effectiveness of the research. Secondary research also entails research material publishes either in research journals, reports or similar documents. Often, such documents are made available by survey data, websites, libraries or even databases. In this case, the research material reviewed is obtained from academic journals available on various online databases such as Sage Publication and Wiley Online Library.

Secondary research goes through four basis steps. The technique starts with the identification of the research topic as well as the best source for the information desired. This is the first step ahead of commencing secondary research. The researcher must define the research area as well as formulate or determine the research questions that the study is bound to answer at the end of the research. In basic terms, the researcher needs to narrow down the scope of the research topic, determine the research domain as well as finalize the source of information which can enhance the collection of the required data.

The second step involves the collection of existing data. Upon successful identification of the source and area of research, the researcher should progress to the existing data collection step and subsequently breaking it down for concrete research results. The researcher should then compare existing data from variant sources and normalize such data. Often, data that is accessed from various sources exists in variant formats. This demands that the researcher normalizes it a single uniform database.

The final step entails data analysis. There is need for the researcher to review the research findings and determine whether the data provides ample relevance to the research topic. The researcher is free to undertake further review of existing data to gain actionable insight into the research topic.

The strengths of secondary research are among the ready availability of most information for use. Arguably, there are many sources of existing and relevant data that the research may gather and utilize as opposed to primary data in which the researcher is tasked with the collection of data from scratch. Secondly, secondary data is less time-consuming and less expensive since the process utilizes easily available data and costs less if collected from sources with justifiable authenticity. Thus, access to data occurs at minimal expenditure. Data gathered through secondary research offers institutions and researchers a general idea regarding the demands of primary researchers. As such, the researcher is able to generate a working hypothesis and assess the estimate primary research cost. Lastly, secondary research is quicker to conduct owing to the convenience of data availability. The research takes a fairly short time depending on data scale demanded of business objective for the research. 


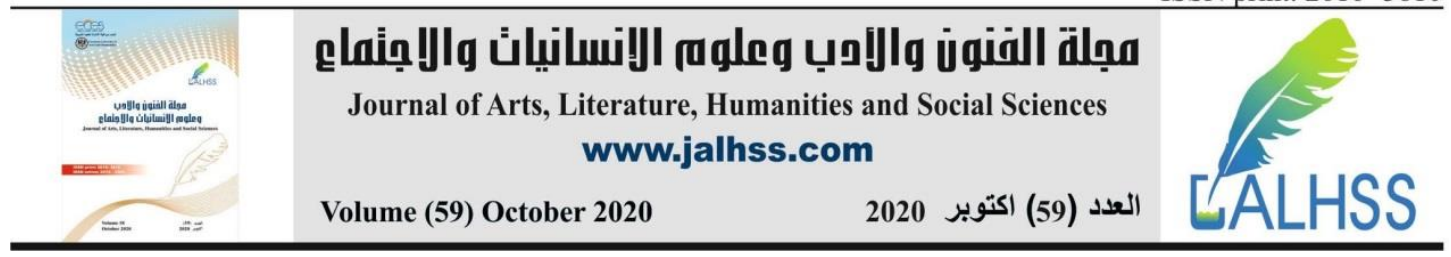

Even so, there are disadvantages of secondary research. While secondary data utilizes readily available data, there is an obvious need for credibility assessment to determine information authenticity. Equally, not all secondary data sources could carry updated statistics and reports despite such data having been true in the past. Lastly, the validity of secondary research relies on, to a greater extent, the validity of primary research.

\section{Findings}

\begin{tabular}{|c|c|}
\hline Author & Michael Harvey and Rodney E. Evans, 1994 \\
\hline Title & Family Business and Multiple Levels of Conflict \\
\hline Journal & Family Business Review \\
\hline Methodology & Change theory and the family life cycle stage model review \\
\hline Findings & $\begin{array}{l}\text { Family businesses offer fertile conflict grounds. It is argued that the } \\
\text { founding families have significant influence on the basic company } \\
\text { culture and beliefs and form a critical foundation for business activity. } \\
\text { Any effort, therefore, which seeks to introduce what is considered as the } \\
\text { norm in the event of progression into the next developmental stage, } \\
\text { there is bound to arise conflict. The individual family units and } \\
\text { company culture overlay make conflict resolution a complex procedure. }\end{array}$ \\
\hline Author & Karam, Filho, \& Abib, 2019 \\
\hline Title & $\begin{array}{l}\text { Conflicts in Boards of Family Firms: A Theoretical Framework for } \\
\text { Strategic Decision-Making }\end{array}$ \\
\hline Journal & Corporate Governance for Family Businesses \\
\hline Methodology & Qualitative review of past publications \\
\hline Findings & $\begin{array}{l}\text { The authors determine that while conflict is a social phenomenon and } \\
\text { can occur just in any organizational form, its intensity is high in family } \\
\text { business dynamics where its understanding is shallow owing to the } \\
\text { property, management, and family psychodynamic interaction effects. }\end{array}$ \\
\hline Author & Laij Victor Effendi, 2020 \\
\hline Title & $\begin{array}{l}\text { The Impact of Family Conflict toward Intention to Stay in the Family } \\
\text { Business: The Moderating Effect of Socioemotional Wealth }\end{array}$ \\
\hline Journal & Jurnal Aplikasi Manajemen \\
\hline Methodology & Quantitative Descriptive Statistics \\
\hline Findings & $\begin{array}{l}\text { The researchers undertake to study the effect of socioemotional wealth } \\
\text { and family conflict on the intention to remain within the family } \\
\text { business. The researchers are also interested in assessing the moderating } \\
\text { socioemotional wealth impact on the effect of family conflict on the } \\
\text { desire to stay. The findings suggest that family conflict negatively } \\
\text { affects the variable 'the intention to stay' and further that } \\
\text { socioemotional wealth yield a positive moderating effect on the family } \\
\text { conflict impact on the stay intention. }\end{array}$ \\
\hline
\end{tabular}




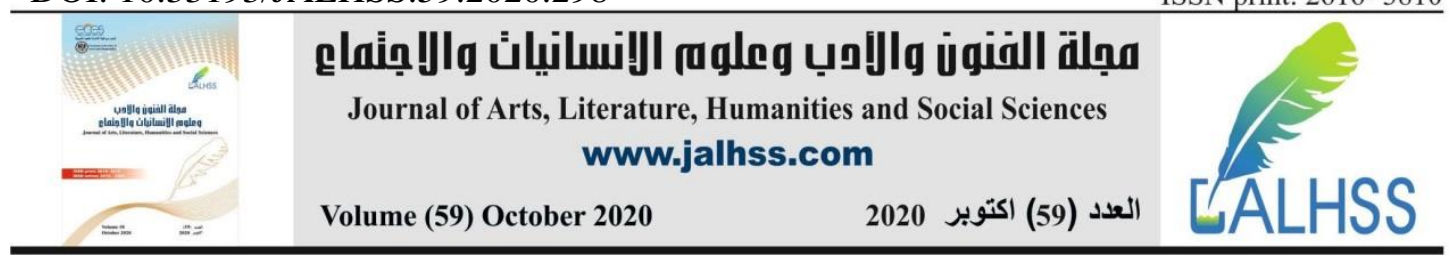

\section{Discussion}

Family business has been justified to be an enabling environment for the progression of conflict. Such conflict is thought to stem from the family's dominant presence, the intertwinement of business and family roles, the absence of formal organizational operating systems and structure, poor communication, the absence of formalized conflict resolution procedures, as well as the family's absolute power and rule setting as noted by Harvey and Evans (1994). Thus, it is critical for the business to determine when the family busines conflict is bound to occur if it is to adopt an effective strategy to its reoslution. Since family businesses ascribe to phase development, the developmental stages should be uitlized in anticipation of conflict and enhance its resolution.

Even if conflict resolution among warring groups might sound as an easy and manageable task. However, it is noteworhty that the process is demanding espcially if the groups involves derive from a family-owned or controlled enterprise. Various research articles indicate through a theoretical model that while board of directors in family-controlled organizations may imply management, it does not necessarily yield the minimization of conflict. The findings from the article by Karam, Filho, and Abib (2019) show that boards with high member competence-based trust levels defined by emotionally cohesive family member presence, decision-making is often marked by little relationship conflict. However, independent member presence is such boards is bound to trigger conflict. Family member incompetence and lack of family cohesion have been positively linked with poor decision-making and stakeholder misunderstanding which trigger conflict.

From the literature reviewed herein, it is arguable that members involved in a conflict in a family business may consider the option of leaving the firm. This is in line with the study conducted by Effendi (2020) in which he studies the possible effect of family conflict on the stakeholder decision to stay in the family business. From the descriptive statistics in the article, the findings on the possible undesirable effect of family conflict on the intention to stay by a stakeholder from a potential successor generation in a family business directly draws from its negative impact on job satisfaction. This implies that conflict in family business is bound to yield feelings of job dissatisfaction since a stakeholder's needs are not met, and, as such, the stakeholder is likely to exit from the family business.

\section{Conclusion and Recommendations}

This paper has identified the impact of conflict on family businesses. Competing family and business identities, variant goals and objectives of stakeholders, the filling of variant business roles by family members alongside as well ineffective communication among the concerned stakeholders are some of the issues and challenges that businesses owned and controlled by families face, with such issues possible leading conflict. Resources reviewed indicate the variant forms of issues, their origins and the correlation with conflict in family businesses. These resources 


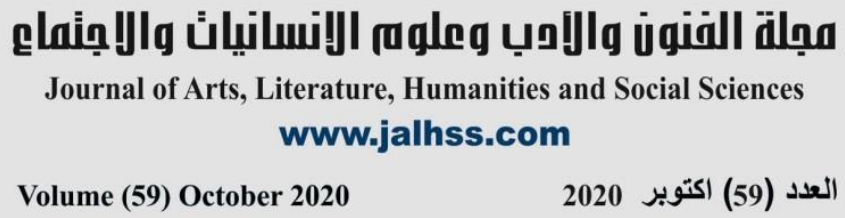

admit that there is need to adopt sound techniques in the resolution of such conflict following careful consideration of its cause.

Recommendations

i) Methods of conflict resolution need to be coordinated to match the conflict complexity. If the professionals seeking to resolve the conflict identify the conflict complexity levels adequately, it becomes possible for the family members to be duly informed on the most efficient techniques for conflict resolution. Equally, the professionals must also review to determine whether such conflict is within potential successor family members or whether external parties are involved. Alternative methods of conflict management should be developed based on the conflict parties and complexity.

ii) The management and stakeholders must never assume that conflict cannot occur in a family business no matter how tightly-knit the family is. It is the role of the management to always understand that family business conflict is a continual dysfunctional event triggered by the unique family organization environment. Thus, it is the role of the management to predict the cause and time of conflict so as to prepare and help families involved in business to manage conflict situations when they arise.

\section{References}

1. Alderson, K. (2015). Conflict management and resolution in family-owned businesses. Journal of Family Business Management, 140-156.

2. Effendi, L. V. (2020). The Impact of Family Conflict toward Intention to Stay in the Family Business: The Moderating Effect of Socioemotional Wealth. Jurnal Aplikasi Manajemen, 64-74.

3. Harvey, M., \& Evans, R. E. (1994). Family Business and Multiple Levels of Conflict. Family Business Review Multiple Levels of Conflict, 7(4).

4. Karam, P. B., Filho, C. A., \& Abib, G. (2019). Conflicts in Boards of Family Firms: A Theoretical Framework for Strategic Decision-Making. Corporate Governance Family Business, 703-720.

5. Li, H., \& Jones, O. (2017). Effectual entrepreneuring: sensemaking in a family-based start-up. Entrepreneurship and Regional Development, 467-501.

6. Salvato, C., \& Sharma, P. (2014). Family firm longevity: a balancing act between continity and change. The Endurance of Family Business, 34-55. 


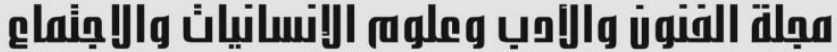

Journal of Arts, Literature, Humanities and Social Sciences www.jalhss.com

7. Schjoedt, L., Monsen, E., Pearson, A., Barnett, T., \& Chrisman, J. (2014). New Venture and Family Business Teams: Understanding Team Formation, Composition, Behaviors, and Performance. Entrepreneurship: Theory and Practice, 1-16.

8. Schneewind, K. A., \& von Schlippe, A. (2015). Theories from Family Psychology and Family Therapy. London: SAGE Publications Ltd.

9. Sherpherd, D., \& Haynie, M. (2010). Family Business, Identity Conflict, and an Expedited Entrepreneurial Process: A Process of Resolving Identity Conflict. Entrepreneurship Theory and Practice.

10. Wally, S., \& Baum, J. R. (2003). Strategic decision speed and firm performance. Strategic Management Journal, 1107-1129.

11. Yanes, E. J. (2015). Family Business Conflict. 1-52. 